\title{
Case Ascertainment and Diagnosis of Stroke in an Epidemiologic Study: The Shibata Stroke Study
}

\author{
Heizo Tanaka, Yutaka Ueda, Chigusa Date, Terumi Baba, Hidetoshi Yamashita, \\ Masayuki Hayashi, Toyonori Horimoto, Kunio Okazaki, Kentaro Yoshikawa, \\ Toyoharu Shimada, Yukari Tanaka and Kunio Owada \\ Department of Public Health, Osaka City University Medical School, Osaka \\ Hironobu Shoji \\ Kyoto Women's University, Kyoto
}

\section{INTRODUCTION}

The diagnosis of stroke in epidemiologic studies is different from that in the field of clinical medicine. The stroke patients are not seen by a staff physician of the epidemiologic study at the onset of the attack; rather, the examination usually takes place sometime after the stroke, even if the investigator ascertains some of the cases himself. The majority of the epidemiologic studies for stroke depend on a history of stroke obtained either from clinical records or from the patient and/or on death certificates, which are later validated by a clinical examination and evaluation by a study physician ${ }^{1,2)}$. Needed information about past events may not be available from clinical records or may not be accurately recorded. Furthermore, because many of the stroke patients in Japan, particularly elderly patients, are traditionally cared for at home by general practitioners, information about the laboratory, Roentgen and special examinations and procedures which are usually carried out at a relatively large hospital may be often unavailable. According to a multicenter stroke register by WHO, only $30-50 \%$ of stroke patients are hospitalized in Japan, whereas about $70-80 \%$ are hospitalized in European countries ${ }^{3)}$. Therefore, many patients of epidemiologic studies for stroke have to be diagnosed according only to their histories and the results of the general and neurological physical examinations noted in the clinical records or performed sometime after the onset by a member of the study team.

Starting in 1976, the Shibata Stroke Study, an epidemiologic study originally designed to investigate stroke, has been under way in two of the nine governmental subdivisions of Shibata City, involved in Niigata Prefecture, Japan. This report presents the methodology of case ascertainment and the accuracy of the diagnosis based solely on history and general and neurological physical examination, as indicated above.

\section{METHODS}

\section{Methodology of Case Ascertainment}

A system of the stroke surveillance has been used in Shibata. All of the residents aged 40 years or above are annually examined at a public building in each section of two city subdivisions where temporary clinics are set up for mass-examination. The items examined are as follows ${ }^{4 \sim 7)}$. Demographic data, smoking habits, dietary habits, alcoholic habits, physical activity habits, medical history of both the subject and his/her family, and subjective symptoms are assessed by questionnaire. Physical and laboratory examinations include anthro- 
pometric measurements of height, weight and skin folds on right triceps and subscapular sites, casual blood pressure, chest X-ray examination, resting electrocardiogram, ocular funduscopy, urinalysis of protein and glucose, blood examinations (serum cholesterol, serum triglyceride, serum HDL-cholesterol, serum vitamin C, serum protein, serum lipoproteins, hemoglobin and hematocrit), and a general and neurological physical examination. If a subject is suspected of having had stroke, he/she will be referred to the stroke surveillance system. Non-respondents are contacted by telephone or visited at their homes by a staff member in order to detect suspected patients of stroke.

In addition to this annual examination, suspected patients of stroke are referred to the surveillance system by all general practitioners in Shibata area $(29$ clinics with beds and 23 clinics without beds) and by the Niigata Prefectural Shibata Hospital (the only general hospital in the city), a private mental hospital, and a nursing home. Patients are also notified by the city's 12 visiting public health nurses, by a laymen's association for stroke control, and by the nearby Kita-Kambara County Hospital in Suibara.

The records of the Division of Emergency Services of the Shibata Fire Department and the social insurance records are also regularly reviewed by a physician from the survey team. Information about fatal strokes is obtained by a review of all death certificates, with supplementary clinical data obtained from the individual certifying physician.

All patients who are alive at the time of referral to the surveillance system are examined by a staff physician, and their clinical histories are reviewed. If the patient is dead at the time of the referral, clinical information is collected from the relatives of the patient together with the certifying physician.

All patient information is entered into the standardized record form which has been revised from the standard WHO form ${ }^{8)}$ (See Appendix 1.). Information collected includes personal identifying information, personal health status prior to stroke, previous medical history, self-care status prior to stroke, early stages of the present attack, clinical state at time of maximal impairment, laboratory and Roentgen findings and the results of other special examinations and procedures performed during the first medical examination, treatment received prior to the present stroke, physical performance at work, dietary habits, smoking habits, alcohol ingestion, etc. This information plus the results of the examination and a review of the hospital's and general practitioner's records are discussed by a group of three staff physicians to determine if the patient meets the criteria as a stroke case. An attempt is made to diagnose the stroke according to anatomical type: subarachnoid hemorrhage, cerebral hemorrhage, cerebral infarction, or of an undetermined type.

\section{Definition and Classification of Stroke}

Stroke is defined as the occurrence of rapidly developing clinical signs of focal or global disturbances of cerebral function, which lasts more than 24 hours or results in death, and for which there is no apparent cause other than a vascular accident ${ }^{8 \sim 10)}$. Transient episodes of cerebral ischemia are excluded by definition.

All strokes are categorized into various subtypes primarily by the clinical judgment of the staff physicians according to the criteria of Millikan, the World Health Organization, Okinaka, and the Japanese Association for Cerebro-Cardiovascular Disease Control ${ }^{1115)}$. Categorization is as follows:

Subarachnoid hemorrhage: The sudden onset of very severe headache with only a relatively momentary disturbance of consciousness, signs of meningeal irritation, the absence of focal neurological signs, and subhyaloid hemorrhage. (The presence of blood in the cerebrospinal fluid, a high density area on the computed tomogram, and ruptured aneurysm and arteriovenous malformation on the angiogram) 
Cerebral hemorrhage: The rapid evolution of focal neurological signs, rapid progression to coma, signs of meningeal irritation, elevated blood pressure, and headache. (Frequently blood-stained cerebrospinal fluid, a high density area on the computed tomogram, and distortion of the usual vessel patterns indicating a hematoma on the angiogram)

Cerebral infarction: A slow, gradual development of focal neurological signs lasting more than 24 hours, relative preservation of consciousness, and elevated blood pressure. This category includes cerebral embolus with a sudden onset of focal neurological symptoms and evidence of emboli. (The absence of blood in the cerebrospinal fluid, a low density area on the computed tomogram a few days after onset, and stenotic or occlusive lesions of the intracranial and extracranial arteries and other findings on the angiogram) Undetermined type: A history of onset and residual deficit sufficiently well documented to ensure a high probability that stroke has occurred but incomplete clinical data to further subcategorize the type of stroke ${ }^{16)}$.

\section{A Study of Diagnostic Accuracy}

The diagnostic methods of acute stroke at the level of the epidemiologic study in Shibata are summarized in Appendix 2. In the Shibata Stroke Study, diagnostic methods, including those of limited availability such as lumbar puncture, computed tomography (CT) and angiography, are available to 30 to $40 \%$ of the cases. More than $60 \%$ are diagnosed and categorized into subtype mainly on the basis of their histories and the findings of general and neurological physical examinations. In addition, autopsy data are available in less than $10 \%$ of the fatal cases. This report estimates the accuracy of diagnosis according to personal history and the general and neurological physical examinations. This diagnosis will be hereinafter called "the clinical judgment".

A special study was carried out on 143 stroke patients and 48 nonstroke patients admitted to a specialized hospital for the treatment of stroke in Osaka, Japan. The age and sex distribution of these subjects is presented in Table 1. The nonstroke patients consist

Table 1 Subjects by age and sex

\begin{tabular}{c|l|l|r|r|r|r|r|r|c}
\hline \multicolumn{2}{c}{ Age } & $30-39$ & $40-49$ & $50-59$ & $60-69$ & $70-79$ & $80-$ & Total \\
\hline \multirow{5}{*}{ Stroke } & Male & 1 & 5 & 3 & 0 & 2 & 0 & 11 \\
\cline { 2 - 9 } & Subarachnoid \\
hemorrhage & Female & 0 & 1 & 0 & 2 & 5 & 0 & 8 \\
\cline { 2 - 9 } & Cerebral hemorrhage & Male & 1 & 1 & 2 & 13 & 9 & 2 & 28 \\
& & Female & 1 & 4 & 5 & 5 & 7 & 0 & 22 \\
\cline { 2 - 9 } & Cerebral infarction & Male & 1 & 3 & 9 & 16 & 13 & 3 & 45 \\
& Female & 0 & 2 & 5 & 9 & 10 & 3 & 29 \\
\hline \multirow{2}{*}{ Nonstroke } & Male & 3 & 5 & 6 & 7 & 6 & 1 & 28 \\
& Female & 3 & 4 & 4 & 5 & 3 & 1 & 20 \\
\hline
\end{tabular}

(All subjects were admitted to a hospital specialized in stroke treatment in Osaka)

of those with one of the following diseases; brain tumor, subdural hematoma, head trauma, brain abscess, and sudden death within 2 hours but confirmed by autopsy as of nonstroke origin. All subjects were assigned clinical judgment only. The clinical judgment was made with particular attention to the following information: age, sex, blood pressure before stroke, preceding transient ischemic attacks, prodromes, blood pressure after onset of stroke, onset, headache, vomiting, level of consciousness, conjugated eye deviation, anisocoria, light reflex, corneal reflex, speech disturbances, neck stiffness, motor deficit, and sensory deficit. These 
items are detailed in Appendices 1 and 2. This clinical judgment was then compared with a diagnosis of the same individual following completion of CT, angiography, brain scan, lumbar puncture, echoencephalography, electroencephalography, and other diagnostic methods. The diagnosis according to $\mathrm{CT}$ and a variety of other procedures will hereinafter be called "CT+diagnosis". For suspected stroke cases, CT was the first and only method that permitted a straightforward, reliable differential diagnosis of cerebral infarction and intracerebral hematoma, as well as determining the exact location of both types of lesion ${ }^{17)}$.

Clinical judgment was made either (1) by a neurologist, (2) by an internist, or (3) by a group of three physicians (a stroke epidemiologist and two neurologists).

\section{RESULTS AND DISCUSSION}

According to a survey of epidemiologic studies of stroke conducted by the American Heart Association ${ }^{11}$, the majority of the studies in the United States ascertained patients from the hospital records, from the reports of attending physicians or patients, and from death certificates, and also included an examination by a physician from the study. In 10 out of 40 studies, however, the examination by the study physician took place more than 6 months after the attack, and it did not occur in 14 of the studies. And their diagnostic methods depended on hospital's or general practitioner's records of stroke patients reviewed by members of the study team and on the history of stroke symptoms obtained from the patient. Many of the representative prospective studies in Japan have followed the same methods of case ascertainment and diagnosis of stroke as those by American studies ${ }^{18,19)}$. Thus, in epidemiologic studies in the United States as well as in Japan, the antemortem diagnosis of stroke rests primarily on evaluation of signs and symptoms, namely, clinical judgment, rather than on the results of laboratory examination, or those revealed by Roentgen and other special examinations and procedures. One of the reasons is that as yet there has been no simple objective measure (analogous to the electrocardiogram for cases of myocardial infarction) to confirm the diagnosis of stroke ${ }^{1)}$. In the Shibata Study, we have included the same sources of case ascertainment as those from other studies and have examined all living patients within three weeks of occurrence by ourselves. In addition, CT or other procedures have been used for 30 to $40 \%$ of the stroke patients seen in the Shibata Stroke Study. More than $60 \%$, however, have been diagnosed on the basis of clinical judgment only, because they are cared for at home by general practitioners. Moreover, autopsy data are rarely available.

In the past, there has been considerable discussion in the literature about the accuracy of the determination of stroke, (and thus its frequency), in Japan. Goldberg and Kurland doubted the diagnostic accuracy of stroke in Japan, dealing with the international comparison of stroke mortality ${ }^{20)}$. Kurtzke emphasized that the high mortality rates for cerebral hemorrhage and probably all strokes in Japan were nothing more than artefacts of diagnostic fashion $^{21)}$.

For this reason, an estimate of the accuracy of clinical judgment is necessary. Ordinarily, an estimate of the accuracy would be a comparison with autopsy findings. However, autopsies are very difficult to obtain in Japan because of traditional or religious custom. In addition, pathological findings after the death may differ from those at the onset of the illness ${ }^{22,23)}$. Fortunately, CT has been developed recently. Therefore, a comparison between clinical judgment and CT +diagnosis was made by using the subjects admitted to a special hospital for stroke in Osaka, because the number of the stroke patients examined by CT and other procedures in the Shibata Study was insufficient to offer the diagnostic accuracy. 
Table 2 The rate of agreement for stroke and nonstroke diagnoses (\%)

\begin{tabular}{l|lrl|r|r|r}
\hline \multicolumn{1}{c|}{ Diagnostician } & CT+ & Clinical judgment & Stroke & Nonstroke & Undetermined \\
\hline \multirow{2}{*}{ A neurologist } & Stroke & $100 \%$ & $(143)$ & 93.7 & 5.6 & 0.7 \\
& Nonstroke & $100 \%$ & $(48)$ & 8.3 & 89.6 & 2.1 \\
\hline \multirow{2}{*}{ An internist } & Stroke & $100 \%$ & $(143)$ & 92.3 & 2.8 & 4.9 \\
& Nonstroke & $100 \%$ & $(48)$ & 4.2 & 91.7 & 4.2 \\
\hline \multirow{2}{*}{$\begin{array}{l}\text { One epidemiologist and } \\
\text { two neurologists }\end{array}$} & Stroke & $100 \%$ & $(143)$ & 97.2 & 2.8 & 0 \\
\hline
\end{tabular}

( ): Number of subjects

Table 3 The rate of agreement for stroke subtype diagnoses

\begin{tabular}{|c|c|c|c|c|c|}
\hline Diagnostician & $\mathrm{CT}+\mathrm{Clinical} \mathrm{judgment}$ & \begin{tabular}{|c|} 
Subarach- \\
noid \\
hemorrhage
\end{tabular} & $\begin{array}{c}\text { Cerebral } \\
\text { hemorrhage }\end{array}$ & $\begin{array}{l}\text { Cerebral } \\
\text { infarction }\end{array}$ & $\begin{array}{l}\text { Undeter- } \\
\text { mined } \\
\text { type }\end{array}$ \\
\hline \multirow{3}{*}{ A neurologist } & Subarachnoid hemorrhage $\underset{(19)}{100 \%}$ & 63.2 & 31.6 & 0 & 5.3 \\
\hline & $\begin{array}{lc}\text { Cerebral hemorrhage } & 100 \% \\
(50)\end{array}$ & 4.0 & 64.0 & 26.0 & 6.0 \\
\hline & $\begin{array}{cc}\text { Cerebral infarction } & 100 \% \\
(74)\end{array}$ & 1.4 & 20.3 & 75.7 & 2.7 \\
\hline \multirow{3}{*}{ An internist } & $\begin{array}{c}\text { Subarachnoid hemorrhage } 100 \% \\
(19)\end{array}$ & 68.4 & 15.8 & 5.3 & 10.5 \\
\hline & $\begin{array}{cc}\text { Cerebral hemorrhage } \quad 100 \% \\
(50)\end{array}$ & 2.0 & 60.0 & 36.0 & 2.0 \\
\hline & Cerebral infarction & 0 & 6.8 & 90.5 & 2.7 \\
\hline \multirow{3}{*}{$\begin{array}{l}\text { One epidemiolo- } \\
\text { gist and two } \\
\text { neurologists }\end{array}$} & Subarachnoid hemorrhage $\underset{(19)}{100 \%}$ & 68.4 & 31.6 & 0 & 0 \\
\hline & Cerebral hemorrhage & 2.0 & 86.0 & 10.0 & 2.0 \\
\hline & Cerebral infarction & 0 & 10.8 & 82.4 & 6.8 \\
\hline
\end{tabular}

( ): Number of subjects

Tables 2 and 3 show the results of comparisons between clinical judgment and CT + diagnosis. The rates of agreement for all strokes and nonstrokes (Table 2) were reasonably high, even if the clinical judgment was performed by only one neurologist or internist. But the rate rose to $97.2 \%$ for all types of stroke combined and to $97.9 \%$ for nonstrokes, when the diagnosis was considered by a group of three physicians. According to Kagan et al. ${ }^{24}$, a comparison between autopsy data and clinical judgment showed that only $70 \%$ of new stroke cases were correctly diagnosed clinically before autopsy. Shimamoto and his colleagues, in a similar study, reported the sensitivity of the clinical judgment was 135 of 138 stroke patients or $97.8 \%$ and that the specificity was 123 of 127 nonstrokes or $96.9 \%{ }^{25)}$.

In this study, three of the four stroke patients were incorrectly diagnosed as subdural hematoma cases by the group of three physicians, although these three patients were, in fact, the cases of infarction in nuclei cerebri which appeared a few months after traffic accidents that involved injury to the head. The fourth patient confirmed to have had cerebral infarc- 
tion by the CT + diagnosis was incorrectly diagnosed because he had no neurological deficit but showed muscle atrophy in his right pelvic limb. A woman, aged 82 years, without any $\mathrm{CT}+$ findings which suggested stroke, was regarded as a cerebral infarction case because of the speech disturbance and the weakness and numbness in her left hand which persisted until her death.

Table 3 shows that the rates of agreement were $63.2 \%$ and $68.4 \%$ for subarachnoid hemorrhage, $64.0 \%$ and $60.0 \%$ for cerebral hemorrhage, and $75.7 \%$ and $90.5 \%$ for cerebral infarction, if clinical judgments were made by a neurologist and by an internist, respectively. That is to say, the rate for cerebral infarction was high, although those of cerebral hemorrhage and subarachnoid hemorrhage were relatively low. If the clinical judgment was considered by a group of three physicians, the rate for cerebral hemorrhage increased to $86.0 \%$, but the diagnostic accuracy for subarachnoid hemorrhage did not improve. The results of a study comparing clinical judgment with autopsy diagnosis in Japan indicated a correct diagnosis in $80 \%$ of 15 subarachnoid hemorrhages, $71 \%$ of 73 cerebral hemorrhages, and $83 \%$ of 47 cerebral infarctions ${ }^{25)}$. Katsuki, in the Hisayama Study, reported that the clinical judgment agreed with the results of autopsies in $86 \%$ of subarachnoid hemorrhages, $70 \%$ of cerebral hemorrhages, and $85 \%$ of cerebral infarctions ${ }^{26)}$. In the United States, on the other hand, there was no epidemiological study which clearly demonstrated the validity of diagnosis of stroke subtypes.

Some investigators reported that cerebral hemorrhage had a tendency to be over-diagnosed at the expense of cerebral infarction, particularly in Japan ${ }^{20,21,24)}$. In our clinical judgment, there was a tendency to regard some of the lateral types of cerebral hemorrhage with slight or no disturbance of consciousness as cerebral infarctions, and to regard cerebral infarctions caused by the occlusion of extracranial vessels and those occurring at the brainstem as cerebral hemorrhages. Thus, the frequency of cerebral hemorrhage diagnosed incorrectly as cerebral infarction by the group of three physicians was $10.0 \%$ and the reverse occurred in $10.8 \%$ (Table 3 ).

There were also some cases in which it was difficult to make a differential diagnosis between subarachnoid hemorrhage and cerebral hemorrhage. Some of the subarachnoid hemorrhages with motor deficit and with neither severe headache nor neck stiffness were incorrectly thought to be cerebral hemorrhages, and some of the pontine hematomas to be subarachnoid hemorrhages. About $32 \%$ of the subarachnoid hemorrhages were incorrectly diagnosed as cerebral hemorrhages, as presented in Table 3.

On the whole, however, if clinical judgment was considered by a group of three physicians, the sensitivity and specificity of the clinical judgment was high, and the rates of agreement as to stroke subtypes were also acceptable. It should be noted, however, that CT has a few limitations for differentiating some types of cerebral infarction and cerebral hemorrhage in their late stages, and that CT remains normal in the majority of cases with cerebral infarction scanned after intervals as long as 8 to 24 hours $^{22}$.

It is well known that there exists intra-observer and inter-observer variation in clinical judgment of stroke, although the present report has not dealt with reliability. A WHO collaborative study has recommended that quantitative diagnostic methods or scoring methods should be applied to the differential diagnosis of stroke in order to improve inter-observer agreement $^{27)}$. The quantitative methods $^{27)}$ were based on scores for selected neurological signs and a few personal characteristics such as age, sex, and previous history. Most of these methods can not be applied to epidemiologic studies of stroke but rather to the field of clinical medicine in relatively large hospitals in Japan, because some information about the neurological signs, particularly that about the findings of lumbar puncture which are 
always employed in scoring methods, is difficult to obtain in epidemiologic studies. Therefore, further studies will be needed to develop other useful quantitative methods for the differential diagnosis of stroke in epidemiologic studies.

\section{SUMMARY}

Beginning in 1976, an epidemiologic study of stroke has been under way in the City of Shibata, Niigata Prefecture, Japan. This report has presented the study's methodology of case ascertainment and the accuracy of diagnosis, namely, clinical judgment, according to patient histories, and general and neurological physical examinations.

In order to ascertain all new stroke patients in Shibata, a surveillance system was employed. The system included annual mass-examination, and referrals by all general practitioners in the Shibata area, the Niigata Prefectural Shibata Hospital, a private mental hospital and a nursing home. Suspected patients were also referred by the 12 visiting public health nurses, by a laymen's association for stroke control, and by the nearby Kita-Kambara County Hospital. The records of the Division of Emergency Services of the Shibata Fire Department and the social insurance records were also regularly reviewed by a physician of the study team. Information about fatal strokes was obtained by review of all death certificates, with supplementary clinical data obtained from the individual certifying physician.

All patients alive at the time of referral were examined by a physician of the study. If the patient was dead, clinical information was collected from the relatives of the patient and the certifying physician.

The information obtained from examinations and a review of the records was entered on a standard form and was evaluated by a group of three staff physicians to determine if the patient met the criteria as a stroke case. If so, an attempt was made to diagnose the anatomical type of stroke.

Since more than $60 \%$ of the stroke patients were diagnosed only on the basis of clinical judgment, the accuracy of this method was estimated using 143 stroke patients and 48 nonstroke patients admitted to a special hospital for stroke in Osaka. If clinical judgment was made by a group of three physicians, $97.2 \%$ of the patients confirmed to have had stroke by computed tomography and other procedures, and $97.9 \%$ of those confirmed as not having had stroke were so designated by the clinical judgment.

Of the 19 subarachnoid hemorrhages, $68.4 \%$ were diagnosed correctly using clinical judgment alone, as were $86.0 \%$ of the 49 cerebral hemorrhages and $82.4 \%$ of the 75 cerebral infarctions. Thus it is concluded that clinical judgment by a group of three physicians is an adequate method to identify stroke cases.

Acknowledgment: Appreciation is extended to the following persons, whose continuing and invaluable support has made this study possible: Drs. Tadayoshi Irino, Minoru Taneda, and Hirao Kaneda (Hanwa Hospital, Osaka) ; Prof. Shuro Nishimura (the Department of Neurosurgery, Osaka City University Medical School) ; Dr. Makoto Ogawa (National Cardiovascular Center, Osaka); and Dr. Keizo Beppu (the First Department of Internal Medicine, Osaka City University Medical School)

\section{REFERENCES}

1) Committee on Criteria and Methods, Council of Epidemiology, American Heart Association (Report prepared by Kuller, L. H., Cook, L. P. and Friedman, G. D.) : Survey of stroke epidemiology studies, Stroke, 3, 579-585 (1972). 
2) Ueda, Y., Tanaka, H., Yamashita, H., Date, C., Baba, T., Shoji, H., Yoshikawa, K., Miyazaki, Y., Nakamura, Y., Horimoto, T., Okazaki, K., Owada, K., Baba, K., Shibuya, M., Hosono, I. and Kon, T.: Stroke incidence according to a community-based registry (Report 1), Jpn. J. Public Health, 26, 215-224 (1979).

3) Hatano, S.: Experience from a multicentre stroke register: A preliminary report, Bull. WHO, 54, 541-553 (1976).

4) Owada, K., Tanaka, H., Ueda, Y., Date, C. and Tanaka, K.: A study on control of cerebrovascular disease, Report 1, Methodology and diagnostic technique, Seikatsu Eisei, 16, 238-250 (1972).

5) Owada, K., Tanaka, H., Ueda, Y., Date, C., Tanaka, K. and Ikegawa, K.: A study on control of cerebrovascular disease, Report 2, Follow-up methodology, Seikatsu Eisei, 17, 8-14 (1973).

6) Owada, K., Date, C., Tanaka, H., Ueda, Y. and Tsue, H.: A simplified method for dietary survey, Rinsho Eiyo, 45, 343-351 (1974).

7) Baba, T., Tanaka, H., Date, C., Ueda, Y., Hayashi, M., Yamashita, H., Shoji, H., Yoshikawa, K., Okazaki, K. and Owada, K.: The outline and validity of the simplified energy expenditure estimation, Jpn. J. Public Health, 27, 259-266 (1980).

8) WHO: Control of stroke in the community, Methodological considerations and protocol of WHO stroke register, Internal Document CVD/S/73.6, Geneva, WHO (1973).

9) WHO: Control of stroke and hypertension in the community, Report of a WHO meeting, Geneva, February 1971, Internal Document CVD/71.3, Geneva, WHO (1971).

10) WHO: Community control of stroke and hypertension, Report of a WHO meeting, Göteborg, November-December 1971, Internal Document CVD/72.1, Geneva, WHO (1972).

11) Ad hoc Committee established by the Advisory Council for the National Institute of Neurological Diseases and Blindness, Public Health Service: A classification and outline of cerebrovascular diseases, Neurology (Minneap.), 8, 395-434 (1958).

12) Ad hoc Committee established by the Advisory Council for the National Institute of Neurological and Communicative Disorders and Stroke, National Institute of Health: A classification and outline of cerebrovascular diseases II, Stroke, 6, 565-616 (1975).

13) WHO; Cerebrovascular disease-Prevention, treatment and rehabilitation, WHO Tech. Rep. Ser. No. 469, Geneva, WHO (1971).

14) Okinaka, S.: Epidemiological study on cerebrovascular disease-Follow-up study during the past three years in 17 cities, towns and villages, Jpn. Med. J. (Nihon Iji Shimpo), 2221, 19-28 (1965).

15) Kimura, N.: Control for diseases of circulatory system. I. Criteria for diagnoses of hypertensive diseases, ischemic heart diseases and cerebrovascular diseases, J.A.C.D., 11, 31-44 (1976).

16) Matsumoto, N., Whisnant, J. P. Kurland, L. T. and Okazaki, H.: Natural history of stroke in Rochester, Minnesota, 1955 through 1969: An extension of a previous study, 1945 through 1954, Stroke, 4, 20-29 (1973).

17) Ambrose, J.: Computerized transverse axial scanning (tomography), II. Clinical application, Bri. J. Radiol., 46, 1023-1047 (1973).

18) Komachi, Y.: Preventive medicine for so-called adult diseases, The trend and control of stroke, Tokyo, Suma-Shobo (1978).

19) Okada, H., Horibe, H., Ohno, Y., Hayakawa, N. and Aoki, N.: A prospective study of cerebrovascular disease in Japanese rural communities, Akabane and Asahi, Part I, Eva'uation of risk factors in the occurrence of cerebral hemorrhage and thrombosis, Stroke, 7, 599-607 (1976).

20) Goldberg, I. D. and Kurland, Z. T.: Mortality in 33 countries from diseases of the nervous system, World Neurol., 3, 444-465 (1962).

21) Kurtzke, J. F.: Race and the Japan story, Chapter VIII, In Epidemiology of cerebrovascular disease, 69-80, Berlin·Heidelberg $\cdot$ New York, Springer-Verlag (1969).

22) Müller, H. R.: The place of computerized tomography and carotid doppler sonography in CV episodes, Advances in Neurology, 25, 181-197 (1979).

23) Kannel, W. B.: Current status of the epidemiology of brain infarction associated with occlusive arterial disease, Stroke, 2, 295-318 (1971).

24) Kagan, A., Katsuki, S., Sternby, N. and Vaněcěk, R.: Reliability of death certificate data on vascular lesions affecting the central nervous system, Bull. WHO, 37, 477-481 (1967).

25) Shimamoto, T., Konishi, M., Ozawa, H., Iida, M., Chikayama, Y., Takahashi, H., Ueshima, H. and Komachi, Y.: The accuracy of stroke diagnosis according to the clinical judgment, A comparison 
with autopsy diagnosis, In Shigiya, K., Komachi, Y. and Watanabe, T, (eds): Nutritional status and diseases of circulatory system in the Japanese, 377-387, Tokyo, Hoken-Dojin-Sha (1976).

26) Katsuki, S.: Hisayama study (Presidential address), Jpn. J. Med., 10, 167-175 (1971).

27) Hatano, S.: Variability of the diagnosis of stroke by clinical judgement and by a scoring method, Bull. WHO, 54, 533-539 (1976).

Appendix 1 Record form for suspected patient of stroke in the Shibata Stroke Study Date of entry $\quad \square \square \square \square \quad 19 \square \square$

Identification number for stroke surveillance Identification number for annual mass-examination Identification number for dietary intake survey Name of patient

Sex
1. male
2. female

Date of birth

Present home address

day month year

Occupation

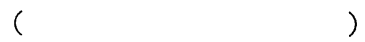

Source of notification

1. hospital record 2. general practitioner

3. nursing home 4. public health nurse

5. death certificate 6 . social insurance record

7. layman's association 8. Fire Department record

9. others (

State of patient at time of notification

1. alive 2. dead

Date of onset

1. a.m. 2. p.m. minute hour day month year

Name of a physician who saw him/her first

day month year

Admission to hospital

) date

Preliminary diagnosis by notifying source

1. no 2. yes. (name of hospital:

) 9. unknown

1. subarachnoid hemorrhage 2. cerebral hemorrhage

3. cerebral infarction 4. undetermined type of stroke

Past history: Stroke

1. no 2. yes 9. unknown

Transient ischemic attacks

1. no 2. yes 9. unknown

Ischemic heart diseases

1. no 2. yes 9. unknown

Hypertension

1. no 2. yes 9. unknown

Diabetes mellitus

1. no 2. yes 9. unknown

Head injury

1. no 2. yes 9. unknown

Other diseases

1. no 2. yes (

) 9. unknown

Patient's capability of self care before stroke

1. independent 2 . partially dependent

3. totally dependent 9. unknown

Control of bladder or bowel before stroke

1. not disturbed 2. disturbed 9. unknown

Description of present illness

[ ]

Clinical state at time of maximum impairment:

Time of onset from first symptom to maximum neurological deficit

Headache
1. no neurological deficit 2 . one to two minutes

3. less than 1 hour 4. more than 1 hour 9. unknown

1. no 2. yes 9. unknown or not assessable 
Level of consciousness

Vomiting

Vertigo or dizziness

Conjugated eye deviation

Anisocoria

Light reflex

Corneal reflex

Speech disturbance

Neck stiffness

Motor deficit of limbs

Sensory paralysis

Impaired bladder or bowel function

Arrhythmia

Presymptoms a few weeks prior to stroke

Blood pressure (First measurement after onset)

Other symptoms and signs

Laboratory examination (describe)
1. fully conscious 2. somnolent or semi-coma

3. coma (less than 24 hours)

4. coma (more than 24 hours) 9. unknown

1. no 2. yes 9. unknown

1. no 2. yes 9. unknown

1. no 2. yes 9. unknown

1. no 2. yes 9. unknown

1. normal 2. lost or slow 9. unknown

1. normal 2. lost 9. unknown

1. no 2. yes 9. unknown or not assessable

1. no 2. yes 9. unknown

1. no 2. weakness/paralysis 9. not assessable

1. no 2. yes 9. unknown or not assessable

1. no 2. yes 9. unknown

1. no 2. yes 9. unknown

1. no 2. yes ( ) 9. unknown systolic diastolic

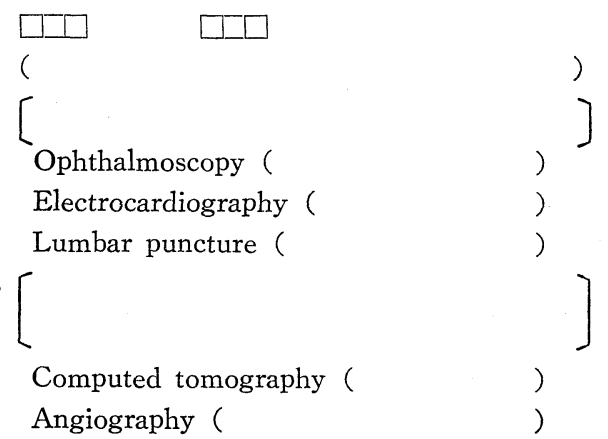

Final diagnosis by study physicians

Roentgen examinations and special procedures (describe).

1. subarachnoid hemorrhage 2. cerebral hemorrhage

3. cerebral infarction 4. undetermined type of stroke

5. nonstroke 6 . undetermined

Appendix 2 Diagnostic methods of acute stroke at the level of the epidemiologic study in Shibata

\begin{tabular}{l|l|c}
\hline & \multicolumn{1}{|c}{ Usually available } & Of limited availability \\
\hline I. History & $\begin{array}{l}\text { 1. Demographic (Sex, Age, etc.) } \\
\text { 2. Family history (Stroke, Hypertension, } \\
\text { Diabetes mellitus, Ischemic heart } \\
\text { diseases, etc.) }\end{array}$ & \\
3. Past history (Hypertension, Heart & diseases, Diabetes mellitus, Transient & \\
ischemic attacks, Head injury, etc.) & 4. Present illness (Onset, Headache, \\
Impaired consciousness, Vomiting, & Vertigo or dizziness, Impaired bladder & \\
and bowel function, etc.)
\end{tabular}




\begin{tabular}{|c|c|c|}
\hline $\begin{array}{l}\text { II. Physical } \\
\text { examination }\end{array}$ & $\begin{array}{l}\text { 1. General (Temperature, Respiration, } \\
\text { Pulse, Blood pressure, Inspection, } \\
\text { Palpation, Auscultation, etc.) } \\
\text { 2. Neurological (State of consciousness, } \\
\text { Conjugated eye deviation, Anisocoria, } \\
\text { Light reflex, Corneal reflex, Visual } \\
\text { disturbance, Speech disturbance, } \\
\text { Neck stiffness, Motor function, } \\
\text { Sensation, etc.) }\end{array}$ & 3. Ophthalmoscopy \\
\hline $\begin{array}{l}\text { III. Laboratory } \\
\text { examination }\end{array}$ & & $\begin{array}{l}\text { 1. Urine analysis (Protein, Glucose, etc.) } \\
\text { 2. Blood analysis (Hemoglobin, White } \\
\text { cell count, Hematocrit, Cholesterol, } \\
\text { Sedimentation rate, Glucose content, } \\
\text { Creatinine level, Serum enzymes, } \\
\text { Blood urea nitrogen, Arterial and } \\
\text { venous blood gas analysis, etc.) } \\
\text { 3. Electrocardiography } \\
\text { 4. Examination of cerebrospinal fluid } \\
\text { (5. Electroencephalography)* } \\
\text { (6. Echoencephalography)* } \\
\text { (7. Ultrasonography)* }\end{array}$ \\
\hline $\begin{array}{l}\text { IV. Roentgen } \\
\text { examination } \\
\text { and } \\
\text { Special } \\
\text { procedure }\end{array}$ & & $\begin{array}{l}\text { 1. Roentgen examination of chest } \\
\text { 2. Roentgen examination of skull } \\
\text { 3. Computed tomography } \\
\text { 4. Cranial angiography } \\
\text { (5. Brain scanning) }{ }^{*} \\
\text { (6. Cerebral blood flow)* }\end{array}$ \\
\hline
\end{tabular}

( )*: Of the future

\title{
疫学的研究における脳卒中患者の把握と診断
}

\author{
田中平三・植田 豊 - 伊達ちぐさ・馬場 眧美 \\ 山下 英年 - 林 正 幸 - 堀本 豊範 - 岡崎 邦夫 \\ 吉川賢太郎・島田 豊治 - 田中ゆかり · 大和田国夫 \\ 大阪市立大学医学部公衆衛生学教室
}

\author{
庄司 博 延 \\ 京都女子大学
}

新潟県 $\mathrm{S}$ 市某地区において脳卒中の疫学的研究が奏施されている。本論文では，乙の研究における脳卒中患者 の把握と診断の方法について検討した。

脳卒中患者の把握のために，次の情報源が利用されている。すなわち，年 1 回の集団検診，開業医および病院 
からの届出，保健婦や住民組織加らの情報，消防本部の救急車出動記録・国民健康保険のレセプト・死亡䛦断書 の定期的閲筧などである。研究に從事している医師は，届出患者を家庭訪問して診察を実施した。全情報は，一 定の書式に整理された。3 人の医師がそれを検討し，脳卒中と非脳卒中，および脳卒中の病型鑑別の診断を行っ た。

患者の60\%以上の診断は，現病歴（臨床経過，臨床症状など）と一般および神経学的理学検查に基づく，いわ

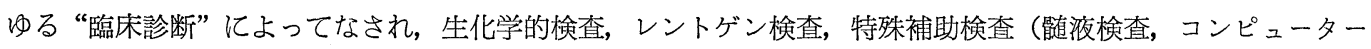
断層撮影，脳血管造影など）などの精密検査に関する情報は得られなかった。そこで，3人の医師による “臨床 䛦断”の妥当性を, コンピューター断圆撮影および他の精密検査結果と比較するととによって検討した。全脳卒 中に対する感度 (Sensitivity) は $97.2 \%$, 特異度 (Specificity) は97.9\%であった。両方法間の一致率は, くも 膜下出血 $68.4 \%$ ，脳出血 $86.0 \%$ ，脳梗塞 $82.4 \%$ であったこのように，充分満足すべき妥当性が得られた。 